\title{
Vase life of cut Lilium pumilum inflorescences with salicylic acid ${ }^{(1)}$
}

\author{
MIRELLE NAYANA DE SOUSA SANTOS ${ }^{(2)^{*}}$, MÁRCIA MARTINS TOLENTINO ${ }^{(3)}$, ANA MARIA MAPELI(3) $^{(3)}$
}

\begin{abstract}
The demand for flowers and ornamental plants has significantly increased in recent years. However, in most cases, the production of such species is accompanied by inappropriate postharvest handling, which is responsible for significant losses of marketed flowers. Lilium pumilum, a member of the family Liliaceae, is one of the ornamental species with economic potential as potted or cut flower, which features long stalks containing orange inflorescences with several flower buds and numerous smooth as well as linear leaves. Due the high perishability of this product, appropriate techniques that extend flower longevity should be employed. The present study was developed to evaluate the effect of salicylic acid (SA) on the postharvest preservation of L. pumilum inflorescences. Stalks were kept in maintenance solution with different concentrations of SA $(0,1,5$ and $10 \mathrm{mM})$ for $0,6,12,18$ and $24 \mathrm{~h}$. The $L$. pumilum flowers had longevity decreased by 57.8 and $63.1 \%$ when kept in 5 and $10 \mathrm{mM} \mathrm{SA}$, respectively, compared with control. This effect may be associated with the observed decrease in the percentages of flower opening and chlorophyll content as well as the damping-off of stalks, indicating phytotoxicity. Therefore, the use of 5 and $10 \mathrm{mM}$ SA is inefficient to extend the longevity of L. pumilum.
\end{abstract}

Keywords: cut flower, floral stalk, lily, longevity.

\section{RESUMO}

Vida de vaso de inflorescências de Lilium pumilum para corte tratadas com ácido salicílico

A demanda por flores e plantas ornamentais tem apresentado aumento significativo nos últimos anos, entretanto, a produção de tais espécies, na maioria das vezes, vem acompanhada do manuseio pós-colheita inadequado, que é responsável por perdas significativas das flores que são comercializadas. Dentre as espécies ornamentais com potencial econômico como flor de vaso ou corte, destaca-se Lilium pumilum, pertencente à família Liliaceae, que se caracteriza por apresentar hastes longas contendo inflorescências alaranjadas com diversos botões florais, folhas numerosas, lisas e lineares. Devido à alta perecibilidade desse produto, a utilização de técnicas adequadas que possibilitem prolongar a longevidade das flores é necessária. Este trabalho teve como objetivo avaliar a influência do ácido salicílico sobre a conservação pós-colheita de hastes florais de L. pumilum. Para avaliar tal efeito, as hastes foram mantidas em diferentes concentrações de ácido salicílico $(0,1,5$ e $10 \mathrm{mM})$ em solução de manutenção, durante $0,6,12,18$ e 24 horas. As flores de L. pumilum apresentaram redução na longevidade de 57,8 e $63,1 \%$ quando mantidas em 5 e $10 \mathrm{mM}$ de ácido salicílico, respectivamente, comparadas ao controle. Este efeito pode estar associado ao decréscimo observado na porcentagem de abertura floral e teor de clorofila, bem como ao tombamento das hastes, demonstrando fitotoxidade. Portanto, o uso das concentrações 5 e $10 \mathrm{mM}$ de ácido salicílico é ineficiente para prolongar a longevidade de L. pumilum nas condições do experimento.

Palavras-Chave: flor de corte, hastes florais; lírio; longevidade.

\section{INTRODUCTION}

In the last years, there was a significant increase in the demand for flowers and ornamental plants. In the twentieth century, the cultivation of ornamental flowers in Brazil aimed primarily at the domestic market. However, the production and sale of these species have followed a worldwide expansion trend, involving exports (LANDGRAF and PAIVA, 2010). A major obstacle to these exports is about the quality and standardization of species, especially regarding perishability and the consequent postharvest loss.

Inadequate postharvest handling is responsible for losses of up to $35 \%$ of all cut flowers sold (STRINGHETA et al., 2002). The main causes of deterioration involve depletion of reserves, especially of carbohydrates consumed during respiration; occurrence of bacteria and fungi; ethylene production; and excessive water loss (NOWAK et al., 1991). Thus, it is highly desirable to inhibit these deteriorating processes.

In this scenario, among the ornamental flowers available in the market, the species of the genus Lilium are widely distributed in temperate environments. These are characterized by the presence of bulbs and rhizomatous roots, leaves alternate and spiral, and stalks containing inflorescence with varying flower buds of diverse colors, which can be orange, yellow, white, red or pink (JUDD et al., 2009). A prominent

DOI: http://dx.doi.org/10.14295/oh.v24i1.1148

(1) Received in 31/01/2018 and accepted in 26/03/2018

(2) Universidade Federal de Viçosa (UFV), Departamento de Biologia Vegetal, Viçosa-MG, Brazil. *Corresponding author: mirellebio@hotmail.com

(3) Universidade Federal do Oeste da Bahia, Centro das Ciências Biológicas e da Saúde, Barreiras-BA, Brazil.

Licensed by CC BY 4.0 
species of this genus is Lilium pumilum Redouté, which stands out in agribusiness by virtue of its ornamental value, marketed as a cut or potted flower (JUDD et al., 2009). Despite its commercial importance, there is limited information on its postharvest physiology as a cut flower.

Among the many deteriorative processes that affect ornamental species, ethylene plays an important role in accelerating senescence, resulting in tissue degradation and a consequent reduction of postharvest life (LIMA et al., 2013). This hormone is produced in all superior plants from the amino acid methionine and the biochemical precursor 1-aminocyclopropane-1-carboxylic acid (ACC), an intermediate in the conversion of methionine to ethylene (YOON, 2015). The physiological effects of ethylene can be blocked by synthesis inhibitors or antagonists. Aminoethoxyvinylglycine (AVG) and aminooxyacetic acid (AOA) inhibit the synthesis of ethylene by reducing the competitive and irreversible activity of ACC synthase, reducing the amount of substrate for ACC oxidase and therefore the conversion of ACC to ethylene (AGARWAL et al., 2012). Another known inhibitor of ethylene production is salicylic acid (SA), which reduces the oxidase activity (FINGER and BARBOSA, 2006; PEREIRA et al., 2017).

Plant hormones are involved in the regulation of senescence in flowers, and changes in the levels of these compounds act as signals to regulate or interrupt specific reactions (MANSOURI, 2012). Studies on the longevity of cut flowers have been conducted in which plant hormones or inhibitors were added to the vase solution, resulting in flowers with delayed senescence (SEREK and REID, 1997; MANSOURI, 2012). SA is regarded as a signal molecule that plays a key role in plant growth, development and protection (DING et al., 2002).
From this perspective, SA has been considered a promising alternative for this purpose and it has various physiological and biochemical functions in plants (MÉTRAUX, 2002). The efficiency of SA in postharvest cut flowers remains unclear. Therefore, the present study was carried out to evaluate the influence of SA on the postharvest preservation of Lilium pumilum stalks.

\section{MATERIAL AND METHODS}

Lilium pumilum inflorescences from Brasilia/DF, Brazil were transported in pots to western Bahia, totaling 40 pots. Before being taken to the laboratory, they remained in a cold room at $5{ }^{\circ} \mathrm{C}$ for $12 \mathrm{~h}$ for acclimatization.

Subsequently, the stalks were immediately taken to the laboratory, trimmed to 25 -cm-long stalks and selected based on absence of mechanical damage and pathogen attack. Cut stalks were placed in solutions with $0(\mathrm{pH}: 6.5), 1(\mathrm{pH}$ : 2.9), 5 (pH: 2.3), and $10 \mathrm{mM}$ (pH: 2.1) SA concentrations.

The pot solution was changed every two days, without cutting the base of the stalk, kept in a growth chamber with $75 \%$ relative humidity at a PAR of $7-10 \mu \mathrm{mol} \mathrm{m} \mathrm{m}^{-2} \mathrm{~s}^{-1}$ illuminated by cool white fluorescent lamps.

Evaluations were carried out daily, considering a) longevity, i.e., the number of days between harvest and loss of flower quality, characterized by the appearance of cracks in the petals and early sagging (BARBOSA et al., 2005); b) floral opening, determined from changes in developmental stages, including S0: green bud flower, S1: bud showing the first petal color, S2: orange bud, S3: semi-open bud, S4: open flower, and S5: wilted flower (Figure 1); c) variation in absorption of the preservative solution; d) chlorophyll content measured by the Minolta SPAD-502 chlorophyll meter, analyzing the basal and apical part of three leaves on each stalk; and e) fresh mass variation.

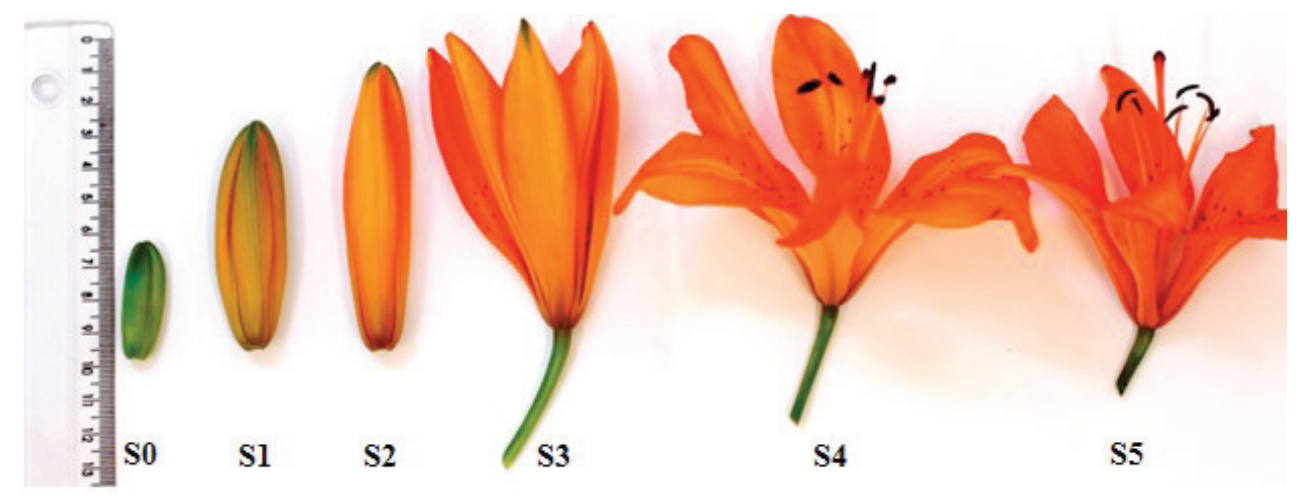

Figure 1. Stages of development of Lilium pumilum. S0: green bud flower; S1: bud showing the first petal color; S2: orange bud; S3: semi open bud; S4: open flower; S5: wilted flower.

The experiment was set up as a randomized block design with four replicates. Each replicate corresponded to two stalks. Data were interpreted using analysis of variance. Means were compared by the Tukey test at 5\% probability. The descriptive analysis of the data included means and standard errors.

\section{RESULTS AND DISCUSSION}

Results showed that application of SA at different concentrations promoted adverse effects depending on the trait considered. In longevity, $1 \mathrm{mM}$ SA elicited a similar response to control (Figure 2). However, the stalks 
exhibited symptoms of phytotoxicity, high stalk inclination and yellowing of leaves (Figure 3), which resulted in an average reduction of $60.5 \%$ in longevity compared with control. The obtained data corroborate those observed by
Cavasini et al. (2015), who suggested that the use of 1,000 mg $\mathrm{L}^{-1} \mathrm{SA}$ in lisianthus (E. grandiflorum) had an adverse effect, since turgescence decreased by $24.6 \%$ after the sixth day and longevity decreased by 8 days, compared with control.

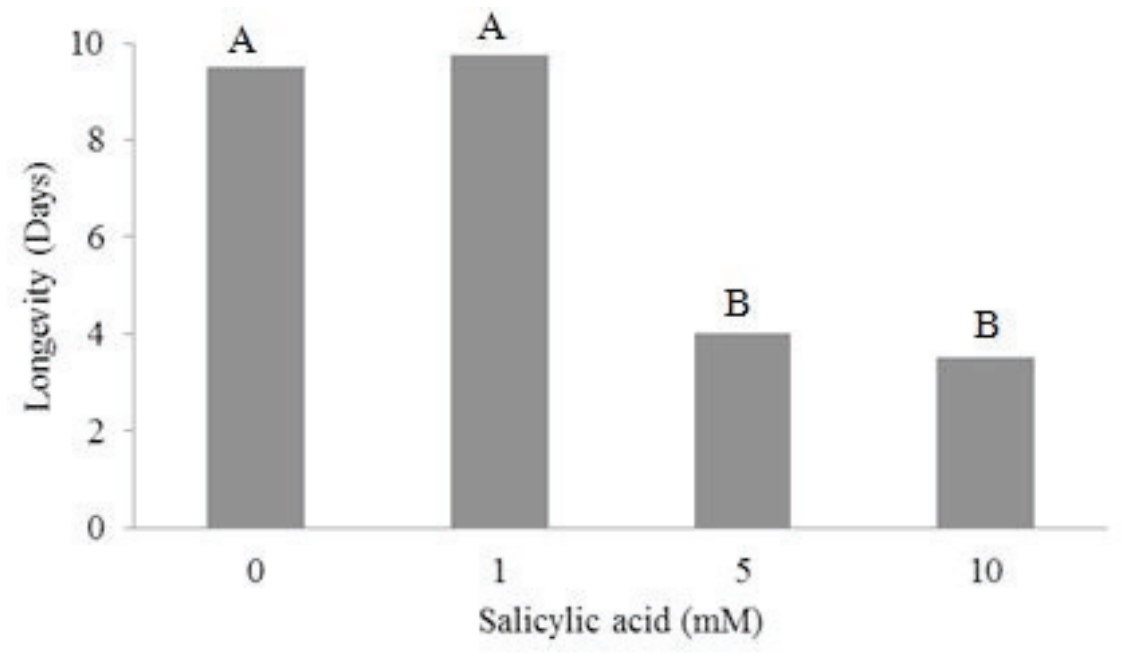

Figure 2. Effect of salicylic acid in different concentrations on longevity of Lilium pumilum inflorescences. Averages followed by the same letter, do not differ by the Tukey test at $5 \%$ probability.

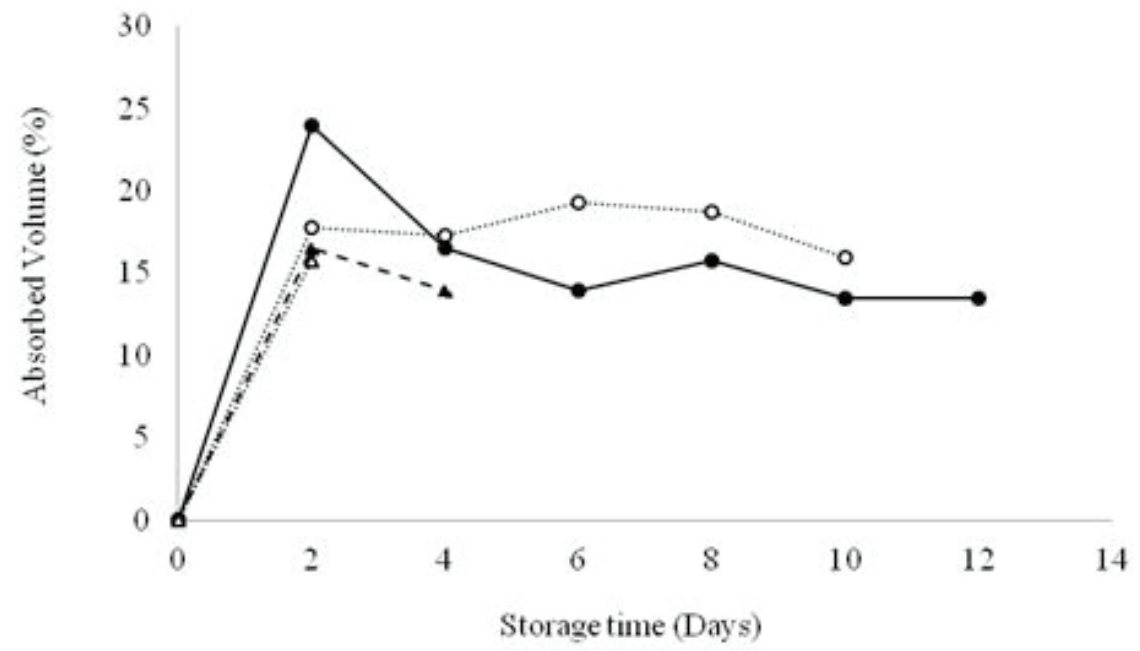

Figure 3. Effect of salicylic acid in different concentrations on absorbed volume of Lilium pumilum inflorescences.

Treatments are symbolized by $(-\mathrm{p}-0 \mathrm{mM}) ;\left(. .{ }^{\mathrm{TM}} \ldots 1 \mathrm{mM}\right) ;(--\mathrm{p}--5 \mathrm{mM}) ;(. . \mathrm{r} . .10 \mathrm{Mm})$.

Flower opening did not change significantly when the stalks were kept in $1 \mathrm{mM} \mathrm{SA}$. However, the other treatments reduced flower opening by $54.9 \%$, on average (Table 1). 
Table 1. Effect of salicylic acid in different concentrations on flower opening in Lilium pumilum.

\begin{tabular}{|c|c|}
\hline Salicylic Acid (mM) & Flower Opening (\%) \\
\hline 0 & $84.3^{\mathrm{A}}$ \\
\hline 1 & $88.5^{\mathrm{A}}$ \\
\hline 5 & $54.5^{\mathrm{B}}$ \\
\hline 10 & $55.2^{\mathrm{B}}$ \\
\hline
\end{tabular}

Averages followed by the same letter, in the column, do not differ by the Tukey test at $5 \%$ probability.

These effects are assumed to be due to the high concentration SA applied as well as the long period of exposure of the stalks to the product. Geerdink et al. (2016) obtained divergent results with Rosa hybrida cv. 'Vega' kept in $1 \mathrm{mM}$ SA for $12 \mathrm{~h}$, which showed reduced respiratory activity and improved water balance.

These data in $L$. pumilum can be explained by the volume absorbed during the experiment, since absorption was higher in control stalks, whereas the other treatments $(1,5$, and $10 \mathrm{mM} \mathrm{SA})$ led to respective decreases of $26.0,31.2$ and $34.3 \%$ after the second day of storage (Figure 4). High concentrations may have contributed to the low absorption, since an increase in solute concentration reduces the ability of water to operate, with a consequent decline in the water potential, causing the stalk to lose water to the solution (COSTA et al., 2015). In addition, the damping-off of the stalks may have been caused by interference with conductance in the xylem of cut flowers or by the accumulation of microorganisms in the solution.

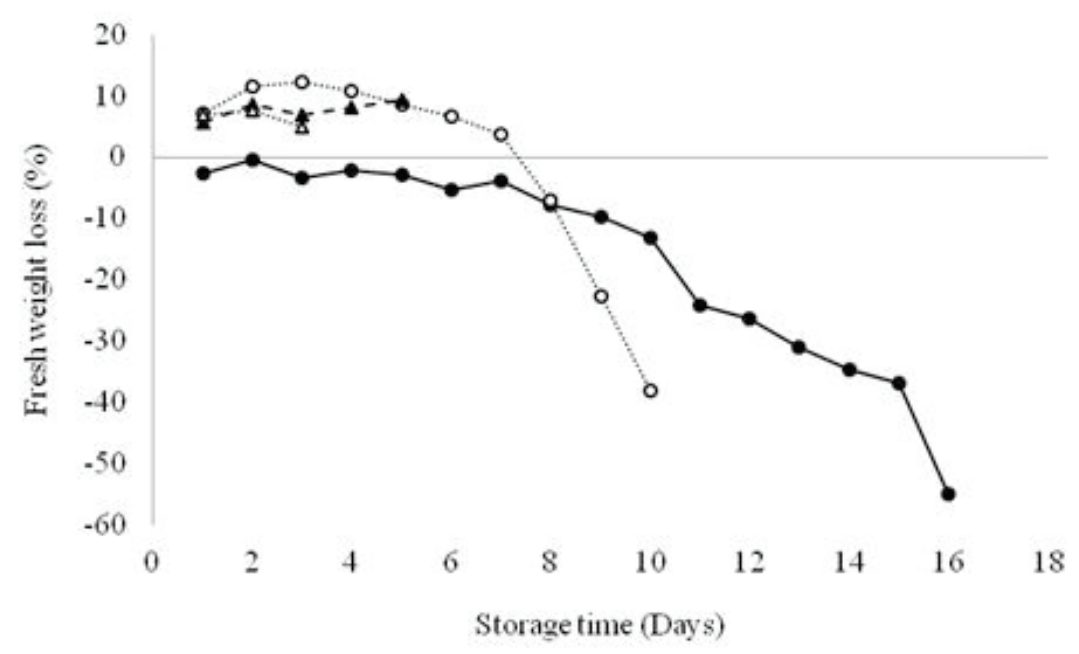

Figure 4. Effect of salicylic acid in different concentrations on fresh weight loss of Lilium pumilum inflorescence. Treatments are symbolized by $(-\mathrm{p}-0 \mathrm{mM}) ;\left(. .{ }^{\mathrm{TM}} \ldots 1 \mathrm{mM}\right) ;(--,--5 \mathrm{mM})$ e $(. . . .10 \mathrm{Mm})$.

In flowers, the harmony of stalks also depends on the leaves, which undergo metabolic changes, mainly a reduction in chlorophyll levels during the senescence process. Our analyses confirm literature reports describing that solution containing $5 \mathrm{mM}$ SA reduced the chlorophyll content by $12.1 \%$ after the fourth day of storage (Table 2), which explains the observed yellowing. When the treatment alone was evaluated, it was found that the stalks kept in 1 mM SA showed significant differences only on the 10th day postharvest compared with the initial day, while $5 \mathrm{mM}$ SA originated changes from the 2 nd day. Furthermore, the stalks conditioned at higher concentrations also showed more pronounced leaf necrosis, and these leaves were discarded on the 4th day, due to loss of quality for sale. 
Table 2. Effect of salicylic acid in different concentrations on chlorophyll content of Lilium pumilum.

\begin{tabular}{|c|c|c|c|c|c|c|c|}
\hline \multirow[t]{2}{*}{ Salicylic Acid (mM) } & \multicolumn{7}{|c|}{ Postharvest (days) } \\
\hline & 0 & 2 & 3 & 4 & 6 & 8 & 10 \\
\hline 0 & $45.4^{\mathrm{Aabc}}$ & $45.4^{\mathrm{Abc}}$ & $45.0^{\mathrm{Aabc}}$ & $47.1^{\text {Aa }}$ & $46.2^{\text {Aab }}$ & $43.4^{\mathrm{Ac}}$ & $43.9^{\mathrm{Ac}}$ \\
\hline 1 & $44.9^{\mathrm{Aa}}$ & $43.9^{\mathrm{Aa}}$ & $44.8^{\mathrm{Aa}}$ & $44.1^{\mathrm{ABa}}$ & $45.8^{\mathrm{Aa}}$ & $40.2^{\mathrm{Ba}}$ & $22.8^{\mathrm{Bb}}$ \\
\hline 5 & $46.5^{\text {Aa }}$ & $43.0^{\mathrm{Ab}}$ & $40.2^{\mathrm{Abc}}$ & $41.4^{\mathrm{Bc}}$ & - & - & - \\
\hline 10 & $46.3^{\mathrm{Aa}}$ & $44.9^{\mathrm{Aa}}$ & $43.8^{\mathrm{Aa}}$ & - & - & - & - \\
\hline
\end{tabular}

Averages followed by the same capital letter in a column and lowercase letters on the lines do not differ significantly by Tukey test at $5 \%$ probability.

Besides the loss of chlorophyll, senescence and commercial unviability are associated with weight loss, which is related to intense transpiration, causing the stalks to wilt, as well as respiration, due to the consumption of the carbohydrate reserve. According to the fresh weight variation on the $2^{\text {nd }}$ storage day, the treatments with SA promoted a rapid increase in mass loss, which was 23.2, 17 and 14.6 times at the SA concentrations of 1,5 and 10 $\mathrm{mM}$, differently from control (Figure 4). The weight loss may be due to water imbalance, since these treatments promoted lower water absorption. In addition, the tissues continued the respiratory process, releasing energy (ATP) for flower opening as well as heat production, which must be dissipated by transpiration, causing the elimination of water.

The lower percentage of fresh weight loss observed in control stalks was also evidenced by Cavasini et al. (2015). By contrast, this loss did not affect the visual appearance of E. grandiflorum, showing that species respond differently to stress.

\section{CONCLUSIONS}

The use of 5 and $10 \mathrm{mM}$ SA is inefficient to extend longevity in L. pumilum. The use of AS at lower concentrations is more appropriate to increase the durability of L. pumilum.

\section{AUTHORS CONTRIBUTIONS}

M.N.S.S and M.M.T designed and performed experiments, analyzed the data, and drafted the article; A.M.M revised and complemented the writing, conceived the project, designed the work, analyzed the data, and wrote the article with contributions of all the authors.

\section{REFERENCES}

AGARWAL G.; CHOUDHARY D.; SINGH V.P.; ARORA A. Role of ethylene receptors during senescence and ripening in horticultural crops. Plant Signaling and Behavior, v.7, p. 827-846, 2012. DOI: https://doi.org/10.4161/psb.20321.
BARBOSA, J.G.; REJANE, A.; FINGER, F.L.; REIS, F.P. Longevidade de inflorescências de lírio em função do estádio de desenvolvimento do botão e do condicionamento em sacarose. Bioscience Journal, v.21, n.2, p.25-31, 2005.

CAVASINI, R.; LASCHI, D.; FAVERO, B.T.; LIMA, G. P. P. Lisianthus vase life after 1-Methylcyclopropene and Salicylic Acid Postharvest Treatment. Acta Horticulturae, v.1060, p.109-114, 2015.

COSTA, L.C.; COSTA, R.R; RIBEIRO, W.S.; CARNEIRO, G.G.; BARBOSA, J.A.; FINGER, F.L. Postharvest longevity of Heliconia wagneriana. Acta Horticulturae, v. 1060, p.93-199, 2015.

DING, C.K.; WANG, C.Y.; GROSS, K.C. Jasmonate and salicylate induce the expression of pathogenesis-relatedprotein genes and increase resistance to chilling injury in tomato fruit. Planta, v.214, n.6, p.895-901, 2002. DOI: https://doi.org/10.1007/s00425-001-0698-9.

FINGER, F.L.; BARBOSA, J.G. Postharvest physiology of cut flowers. In: BENKEBLIA, N.; SHIOMI, N. (ed.). Advances in postharvest technologies for horticultural crops. Kerala: Research Signpost, 2006. p.373-393.

GEERDINK, G.M.; PESSOA, C.O.; TEZOTTO-ULIANA, J.V.; DIAS, G.M.; KLUGE, R.A. Salicylate compounds and 1-Methylcyclopropene on postharvest of 'Vega' cut rose. Revista Iberoamericana de Tecnologia Postcosecha, v.17, p.119, 2016.

JUDD, W.S.; CAMPBELL, C.S.; KELLOGG, E.A.; STEVENS, P.F.; DONOGHUE, M.J. Sistemática Vegetal: um enfoque filogenético. $3^{\mathrm{a}}$ edição. Porto Alegre: Artmed, 2009. 612p.

LANDGRAF, P.R.C.; PAIVA, P.D.O. Exportação de flores e plantas ornamentais do estado de Minas Gerais. Revista Brasileira de Horticultura Ornamental, v.16, p.160-164, 2010. DOI: http://dx.doi.org/10.14295/rbho.v16i2.557.

LIMA, J.D.; MORAES, W.S.; SILVA, C.M. Tecnologia pós-colheita de flores de corte. Revista Brasileira de Horticultura Ornamental, v.14, n.1, p.29-34, 2008. 
MANSOURI H. Salicylic acid and sodium nitroprusside improve postharvest life of chrysanthemums. Scientia Horticulturae, v.145, p.29-33, 2012. DOI: https://doi. org/10.1016/j.scienta.2012.07.016.

MÉTRAUX, J.P. Recent breakthrough in the study of salicylic acid biosynthesis. Trends Plant Science, v.7, n.8, p.332-334, 2002.

NOWAK, J.; GOZXZYNSKA, D.; RUDNICKI, R.M. Storage of cut flowers and ornamental plants: present status and future prospects. Postharvest News and Information, v.2, p.255-260, 1991.

PEREIRA, A.M.; GOMES, M.P.; VIEIRA, J.C.B.; COSTA, L.C.; SILVA, F.C.; FINGER, F.L. Methyl jasmonate and salicylic acid on postharvest physiology of Bird of Paradise. Revista Brasileira de Ciências Agrarias, v.12, p.283-288, 2017. DOI: https://doi.org/10.5039/agraria.v12i3a5450
SEREK, M.; REID, M.S. Use of growth regulators for improving the postharvest quality of ornamentals. Perishables Handling, v.92, p.7-8, 1997.

STRINGHETA, A.C.O.; LIRIO, V.S.; SILVA, C.A.B.; REIS, B.S.; AGUIAR, D.R.D. Diagnóstico do segmento de produção da cadeia produtiva de flores plantas ornamentais do Rio de Janeiro. Revista Brasileira de Horticultura Ornamental, v.8, n.1, p.77-90, 2002.

YOON, G.M. New insights into the protein turnover regulation in ethylene biosynthesis. Molecules and Cells, v.38, p.597-603, 2015. 